\title{
Remigiusz Kasprzycki
}

\section{Kłusownictwo w Drugiej Rzeczypospolitej}

\begin{abstract}
Abstrakt: W II Rzeczypospolitej problem kłusownictwa był bardzo poważnym wyzwaniem i nigdy nie został znacznie ograniczony. W latach 1918-1939 z tym przestępstwem bezskutecznie walczyli policja, straż leśna oraz myśliwi. Kłusownicy byli niebezpiecznymi i nieprzewidywalnymi ludźmi, często zabijali myśliwych, leśników, a także nie wahali się strzelać do policjantów. W międzywojennej Polsce działalność kłusowników poważnie zagrażała istnieniu populacji nawet pospolitych zwierząt.
\end{abstract}

Słowa kluczowe: kłusownictwo, policja, polowanie, II Rzeczpospolita, zwierzęta.

Abstract: Poaching in the Second Polish Republic was a serious problem that was never quite resolved. In 1918-1939, it was actively fought against by the police, forest guards and hunters. Poachers were dangerous and unpredictable people; they often killed hunters and foresters, they did not hesitate to fire at policemen. In interwar Poland poaching was a real threat to species, even to common animals.

Key w or ds: poaching, the police, hunting, Second Polish Republic, animals.

Kłusownictwo jest przestępstwem znanym od wieków i bardzo trudnym do zwalczania we wszystkich krajach na świecie. W określonych warunkach zjawisko to rozwija się w sposób niekontrolowany i intensywny. Sprzyjającymi okolicznościami kłusownictwu są nieskuteczność władzy, popyt na określony gatunek zwierząt i łatwa chęć zysku. Niebagatelną rolę odgrywaja także bieda i pauperyzacja ludności zamieszkującej dany obszar. Istotne również sa tradycja i społeczne przyzwolenie na kłusownictwo w różnych regionach kraju. Temu przestępstwu towarzyszy szczególny brak empatii dla cierpienia zwierząt. 
Problem kłusownictwa w II RP nie doczekał się do tej pory żadnego opracowania naukowego. Co zaskakujacce, nic nie pisano o tym w Polsce Ludowej. To zastanawia, bo paradoksalnie był to świetny pretekst do krytyki sanacyjnej Polski jako kraju z nielegalnie polująca „biedną i głodną ludnością wiejską”, a jednocześnie bezradną wobec tego przestępstwa policją. Kłusownictwem jako odrębnym tematem w międzywojennej Polsce nie zajmowano się także po 1989 r. Nawet autorzy, którzy opisywali regionalne dzieje myślistwa na ziemiach Polski, kwestii kłusownictwa w latach 1918-1939 poświęcali niewiele uwagi.

Niniejszy artykuł ma pionierski charakter i stanowi historyczne rozważania o przyczynach i sposobach walki z kłusownictwem przed 1939 r. Mimo że odwołuję się w nim do ustaw administracyjnych i zachowanej dokumentacji policyjnej, nie śledzę jednak przemian w prawodawstwie i nie dokonuję analizy kompetencji oraz współpracy wszystkich organów administracji państwowej, których zadaniem było zwalczanie kłusownictwa. Chcę natomiast odpowiedzieć, kim byli przedwojenni kłusownicy, a także jakie nieśli zagrożenie dla ludzi i świata zwierząt? Ciekawi mnie, na jakie gatunki zwierząt najchętniej kłusowano i z jakich technik nielegalnego łowiectwa korzystano. Interesuje mnie również, jaki stosunek do kłusowników charakteryzował myśliwych. Czy była to wyłącznie niechęć i pogarda? Dociekam także, czy myśliwi mogli stać się kłusownikami? Do uzyskania odpowiedzi na tak postawione pytania wykorzystuję liczne źródła, w tym publicystykę myśliwska. Nie oznacza to, że mój artykuł odnoszę do dziejów myślistwa w międzywojennej Polsce. Ten ostatni temat stanowi zupełnie odrębne zagadnienie. Stawiam tezę, że to kłusownictwo przez cały okres II RP było poważnym problem i nigdy nie zostało zwalczone. Uważam, że nie wynikało to jedynie ze słabości nowo odrodzonego państwa. Źródeł tej słabości należy szukać w społecznym bagatelizowaniu tego zjawiska, niechlubnej tradycji i chęci łatwego zysku. Zakładam również, że szerokie kręgi niezamożnej ludności wiejskiej, od pokoleń obserwujące i uczestniczace jako pomoc w polowaniach szlachty, a potem ziemiaństwa, poza strachem przed kara nie rozróżniały, że ciche wykładanie wnyków w lasach jest czymś gorszym od głośnych polowań z bronią, nagonką psów i dźwiękiem myśliwskich trąbek. Artykuł nie ma ścisłego układu chronologicznego. Z uwagi na jego charakter problemowy niekiedy do opisanych już wcześniej wydarzeń odwołuję się w dalszej częśsi tekstu.

Na przełomie XIX i XX w., mimo surowych zakazów, kłusownictwo na ziemiach polskich stało się powszechne. O problemie tym bardzo często pisała prasa, np. „Łowiec”, „Hodowca i Myśliwy”. Nasilenie nielegalnego masowego odstrzału, odławiania ryb czy nieskrępowanego zakładania wnyków nastapiło na ziemiach polskich w latach 1914-1918. Doświadczyła tego dobrze rozwinięta gospodarczo zachodnia czesść, np. w okolicach Pszczyny podczas I wojny światowej ogołocono wszystkie zbiorniki wodne z żyjących 
w nich ryb ${ }^{1}$. Całkowitego wytrzebienia tutejszego rybostanu dopełnił czas powstań ślasskich. Jeszcze gorsza sytuacja była na wschodzie i południu kraju, szczególnie $\mathrm{w}$ regionach bogatych $\mathrm{w}$ unikatową florę i faunę. Prawdziwy dramat nastapił w Puszczy Białowieskiej. Wkroczenie wojsk niemieckich do prastarego wielkiego lasu w sierpniu 1915 r. oznaczało jego bezlitosna eksploatację. Niemcy rozpoczęli masową wycinkę lasu, do transportu drewna zbudowano specjalna 130-kilometrową kolejkę wąskotorowa. Przy totalnym wyrębie lasu pracowało kilka tysięcy osób. Byli wśród nich robotnicy z Niemiec, a także rosyjscy i francuscy jeńcy. Największą część zatrudnionych przy karczowaniu pradawnej puszczy - ok. 8 tys. - stanowiła miejscowa ludność. W ciąu trzech lat Niemcy wycięli ok. $5 \mathrm{mln} \mathrm{m}$ sześc. drewna ${ }^{2}$. Równie przerażająca zagłada dotyczyła zwierzyny. Tuż przed wybuchem Wielkiej Wojny w Puszczy Białowieskiej żyło 16 tys. grubej zwierzyny, w tym 500 żubrów. Zwierzęta wybili nie tylko okupujący ją Niemcy, ale przede wszystkim ukrywający się w niej na wiosnę 1919 r. zdemobilizowani żołnierze i dezerterzy z różnych armii. Dramatyczną atmosferę bezlitosnego tępienia tutejszej zwierzyny w swoich wspomnieniach zachował prof. Władysław Szafer, który wraz z prof. Eugeniuszem Kiernkiem i inż. leśnictwa Janem Kloską próbowali w ramach komisji rządowej dostać się do puszczy. Celem misji naukowej było oszacowanie pogłowia żubra. Władysław Szafer po 38 latach pisał:

od świtu do nocy słychać było strzały, nie gęste wprawdzie, lecz stałe. To bandy żołnierzy rozkładającej się armii wybijały w puszczy zwierzynę do nogi. Ustawili się oni na liniach oddziałowych i strzelali z karabinów w las na wysokości brzucha, na ślepo, po czym szli ławą i podnosili wszystką ubitą zwierzynę. Tak wybito niemal zupełnie łosie, jelenie, daniele i żubry - z grubej zwierzyny ocalały tylko dziki ${ }^{3}$.

Bezprecedensowe zmniejszanie się połaci drzewostanu pradawnej puszczy europejskiej przyczyniło się do dramatycznego spadku liczby mieszkających w niej żubrów. W $1916 \mathrm{r}$. Niemcy szacowali, że w puszczy przebywa ok. 200 sztuk gatunków tego zwierzęcia. W marcu 1917 r. żyło tam jedynie 121 sztuk zwierząt, po wkroczeniu wojsk bolszewickich w 1920 r. - tylko jedna żubrzyca, która 9 II 1921 r. zabił Bartłomiej Szpakowicz, gajowy mieszkający we wsi Stoczek ${ }^{4}$. Miejscowa ludność także masowo polowała na dziki, sarny, bobry czy rysie.

Podobnie jak w przypadku Puszczy Białowieskiej, ogromne spustoszenia w Tatrach spowodowała I wojna światowa. Na niedźwiedzie, sarny czy kozice

\footnotetext{
${ }_{1}$ Archiwum Państwowe w Katowicach (dalej: APK), Urząd Woj. Śląski Wydz. Rolniczy (dalej: UWSWR), 673, O podniesienie rybostanu w Pszczyńskim, k. 11.

${ }^{2}$ M. Kwiatkowski, Puszcza Białowieska. Reaktywacja, Warszawa 2011, s. 11-12.

${ }^{3}$ W. Szafer, Pierwsze karty z historii Białowieskiego Parku Narodowego, Warszawa 1957, s. 470.

${ }^{4}$ K. Wróblewski, Żubr puszczy białowieskiej, nakładem Ogrodu Zoologicznego w Poznaniu, Poznań 1927, s. XII.
} 
polowali ukrywający się w górach dezerterzy. Nie tylko w Tatrach - na całym Podhalu i Orawie szczególnie zagrożone były niedźwiedzie. Niekontrolowane pasje myśliwskie okolicznych właścicieli ziemskich, a przede wszystkim kłusownictwo sprawiały, że niedługo po zakończeniu Wielkiej Wojny zadawano pytanie retoryczne: czy sa jeszcze niedźwiedzie w Tatrach?5 Szczególna zawziętość w nielegalnych polowaniach cechowała mieszkańców okolic Zakopanego. Uważano, że w ściganiu niedźwiedzi, kozic i saren sprytem podhalańscy górale przewyższają znacznie górali ze Słowacji. Podczas łowieckich wypraw charakteryzowała ich wzajemna solidarność. Jak twierdzono, upolowana zwierzyną chciwi polscy górale dzielili się zawsze sprawiedliwie ${ }^{6}$. Bezradnym $\mathrm{w}$ walce $\mathrm{z}$ kłusownictwem $\mathrm{w}$ Tatrach polskim służbom już od początku lat dwudziestych stawiano za wzór skuteczne służby czechosłowackie. W tym kraju do walki z nielegalnymi polowaniami skierowano dobrze zorganizowane oddziały straży górskiej i patrole wojska. Na terenie Słowacji bardzo szybko przyniosło to pozytywne rezultaty, bo właśnie w południowym masywie Tatr kozice znajdowały schronienie ${ }^{7}$. Rozbudowane organy bezpieczeństwa nie stanowiły jednak gwarancji skutecznej walki. Plaga kłusownictwa szerzyła się choćby w Związku Sowieckim, gdzie aparatura sądowo-policyjna coraz mocniej kontrolowała miejscową ludność. Mimo zakazów na terenie Białorusi, w latach 1924-1926 znacząco wzrosła skala nielegalnego polowania na bobry ${ }^{8}$. Tym bardziej więc w Polsce zaczęto zdawać sobie sprawę, że w ochronie zwierząt zagrożonych kłusownictwem potrzebne jest ujednolicenie prawa i wprowadzenie nowych regulacji. Do takich prac szybko przystapiła Państwowa Komisja Ochrony Przyrody (PKOP), która powstała 17 XII 1919 r. Od początku stycznia 1920 r. do lipca 1921 r. PKOP przygotowała projekt ustawy ścisłej ochrony rzadkich gatunków zwierząt (żubra, bobra, kozicy i świstaka). Przewidywano, że za zabicie tych zwierząt będą stosowane wysokie kary finansowe (m.in. 200 tys. marek polskich za zabicie żubra) lub kara więzienia od 1 miesiąca do 1 roku. Najsurowsze kary w art. 7 zakładano - jak pisano - dla „przestępców zawodowo niszczących zwierzęta podlegających ochronie". Dla kłusowników miano stosować podwójne kary9 Niestety, tak przygotowane rozporządzenia w walce z kłusownictwem nie doczekały się realizacji. Wielu starostów w pierwszych latach po odzyskaniu niepodległości wciąż bazowało na rozporządzeniach obowiązujących w byłych państwach zaborczych. Na ujednoliconą ustawę łowiecką długo czekało także

\footnotetext{
${ }^{5}$ S. Barabasz, Niedźwiedź w Tatrach, nakład Polskiego Towarzystwa Tatrzańskiego, Kraków 1929 , s. 28.

${ }^{6}$ Ibidem, s. 27.

${ }^{7}$ M. Świerz, Kozice w Tatrach, „Łowiec. Organ Małopolskiego Towarzystwa Łowieckiego” 1922, nr 11, s. 9.

${ }^{8}$ Ochrona przyrody w Rosji Sowieckiej, „Ochrona Przyrody” 1927, nr 7, s. 90.

${ }^{9}$ Część Urzędowa. Ogólne sprawozdanie za czynności Państwowej Komisji Ochrony Przyrody za okres od 1 stycznia do 30 lipca 1921, „Ochrona Przyrody” 1921, nr 2, s. 95.
} 
środowisko myśliwskie ${ }^{10}$. Nadzieję na poprawę sytuacji przyniosło dopiero rozporządzenie z grudnia 1927 r., o którym piszę w dalszej części artykułu. Po odzyskaniu niepodległości państwo polskie było słabe, nie wiadomo, czy wprowadzenie odpowiednich przepisów przeciw kłusownictwu przyniosłoby oczekiwane zmiany. Struktury sądowo-policyjne odrodzonej Rzeczypospolitej dopiero tworzono, a wspomnianego problemu na tle innych przestępstw nie uważano za priorytetowy. O wiele większe zagrożenie stanowił fakt, że po niedawnej wojnie w rękach prywatnych, w tym kłusowników, znajdowała się różnego rodzaju broń. Leśnicy podejmujący często niełatwą i niebezpieczna z nimi walkę byli zaś słabo uzbrojeni. Sami nabywali broń w zupełnie dziwnych okolicznościach, która służyła im do odparcia ataku uzbrojonych kłusowników $^{11}$. Jeden z pierwszych i podstawowych sposobów walki z kłusownictwem stanowiło rekwirowanie broni, w tym typowo myśliwskiej. Skonfiskowana broń była wystawiana na licytacje. W kwietniu 1921 r. starosta gnieźnieński informował wojewódzki wydział leśny w Poznaniu, że za skonfiskowane fuzje myśliwskie i broń myśliwską uzyskano 10410 marek polskich ${ }^{12}$, jednak już w kolejnych latach konfiskaty broni i licytacje wzbogacajace skarb państwa zmalały. Sądy nie wykazywały pośpiechu w orzekaniu kar wobec osób, którym zabrano broń służąca do nielegalnego polowania. W sierpniu 1923 r. starosta w Ostrzeszowie stwierdzał, że już od kilku lat władze sądowe nie przekazały starostwu skonfiskowanej broni na licytację, a także nie wymierzyły kary jej byłym właścicielom ${ }^{13}$. Skutki kłusownictwa w Polsce nie zmalały w kolejnych latach. Według obliczeń „Rocznika Statystyki Polski” tylko w 1928 r. oficjalnie odnotowano 8348 przypadków kłusownictwa ${ }^{14}$. W ramach walki z kłusownictwem broń konfiskowano do końca II Rzeczypospolitej. Tylko na terenie podległym Komendzie Powiatowej Policji Państwowej w Lubartowie w I kwartale 1939 r. przejęto od kłusowników 20 sztuk broni, a ponadto zlikwidowano 73 sztuki wnyków i 20 sztuk sideł ${ }^{15}$. Konfiskata broni myśliwskiej był jednym z najważniejszych środków walki z kłusownictwem polskiej policji. Nota bene stanowiła jedna z dodatkowych wskazówek dla funkcjonariuszy, płynacca z Komendy Głównej Policji Państwowej (KGPP), o czym w dalszej części artykułu.

${ }^{10}$ B. Miśkiewicz, Z dziejów towiectwa w Wielkopolsce, Poznań 1995, s. 89.

11 Archiwum Państwowe w Poznaniu (dalej: APP), Dyrekcja Lasów Państwowych w Poznaniu (dalej: DLPP), 97, Pismo starosty Śremu do wojewódzkiej Dyrekcji Lasów Państwowych w Poznaniu, Śrem, 1 VI 1920.

${ }^{12}$ Ibidem, Pismo starosty gnieźnieńskiego do wojewódzkiego wydziału leśnego w Poznaniu, Gniezno 14 IV 1921.

${ }^{13}$ Ibidem, Pismo starosty ostrzeszowskiego do wojewody w Poznaniu, Ostrzeszów 31 VIII 1923.

${ }^{14}$ Dwudziestolecie międzywojenne, t. XXXIV: I. Kienzler, Darz bór (myśliwi i leśnicy), Warszawa 2014, s. 34.

15 Archiwum Państwowe w Lublinie (dalej: APL), Komenda Powiatowej Policji Państwowej w Lubartowie (dalej: KPPPL), 175, Raport dotyczący zwalczania kłusownictwa podpisany przez Józefa Krzeczkowskiego Komendanta PP w Lubartowie wysłany do Komendanta Wojewódzkiego Urzędu Śledczego PP w Lublinie, Lubartów 4 IV 1939. 
Szybko okazało się, że w walce $\mathrm{z}$ kłusownictwem istotne było nie tylko odbieranie broni myśliwskiej czy niszczenie sideł lub wnyków, ale także ściganie osób zajmujących się handlem i dystrybucją nielegalnie upolowanej zwierzyny. Nie było to łatwe zadanie. Z jednej strony, szczególnie na prowincji, sprzedający pod koniec lat trzydziestych wciąż czuli się zupełnie bezkarni, a policja wykazywała pod tym względem dużą opieszałość. Jak pisał podinspektor Stanisław Ruciński, naczelnik Urzędu Śledczego Komendy Policji Państwowej w Lublinie: „Włościanie i domokrążni handlarze jawnie nosza nielegalnie ubitą zwierzynę, którą sprzedaja po niskich cenach w sklepach, jatkach itp. Stan taki wskazuje na to, że policjanci nie przejawiają najmniejszego zainteresowania $\mathrm{w}$ tym kierunku" ${ }^{\prime 6}$. W rozkazie zalecano wzmożenie kontroli każdej podejrzanej zwierzyny, która była transportowana lub wystawiona na sprzedaż. Wkrótce z podległych komend i posterunków lubelskiego okręgu policji zaczęły napływać meldunki. W większości sprawozdań raportowano, że problem handlu nielegalnie upolowaną zwierzyną nie istnieje. W świetle pisma Rucińskiego tego rodzaju doniesienia można ocenić raczej jako bezradność niż skuteczność policji.

Do sumienia restauratorów niejednokrotnie odwoływał się Centralny Związek Polskich Stowarzyszeń Łowieckich. Zwracano się z apelem o zaprzestanie nabywania upolowanej zwierzyny z rąk kłusowników, wzywano do wskazywania na tego rodzaju przestępców policji. Współpraca niektórych restauratorów i kłusowników w przedwojennej Polsce przybrała zatrważające rozmiary. Z niepokojem informowało o tym choćby Wileńskie Towarzystwo Myśliwskie: „My byśmy też mogli wymienić te firmy wileńskie, które współpracują z pętlarzami i kłusownikami w tępieniu zwierzyny. Nie czynimy tego, bo musielibyśmy wymienić wszystkie restauracje wileńskie" ${ }^{17}$. Towarzystwo ostrzegało miejscowych restauratorów, że osoby prowadzące taką działalność nie tylko poniosa odpowiedzialność karna, lecz ich nazwiska trafią na czarna listę, którą opublikuje prasa lokalna.

Kłusownictwu sprzyjały surowe zimy. Srogi mróz, a zwłaszcza obfite opady śniegu sprawiały, że wygłodniała zwierzyna szukała pożywienia w pobliżu wiejskich zabudowań. Zimą kłusownicy więc, zupełnie bezpieczni, rozkładali sidła blisko domów. Fakty takie rejestrowała nie tylko policja, ale i urzędy wojewódzkie. To niepokojące zjawisko dostrzegł m.in. na początku lutego 1937 r. Urząd Wojewódzki w Poznaniu:

Doszło do wiadomości Urzędu Wojewódzkiego, że z powodu długotrwałych silnych mrozów i obecnie także spadłych śniegów zwierzyna, a zwłaszcza kuropatwy, bażanty

${ }^{16}$ Ibidem, Pismo podinspektora Stanisława Rucińskiego, naczelnika Urzędu Śledczego Komendy Wojewódzkiej Policji Państwowej w Lublinie dotyczące zwalczania kłusownictwa, Lublin 15 XII 1938.

${ }_{17}$ Odezwa Centralnego Zwiazku Łowieckiego Polskich Stowarzyszeń Eowieckich, „Gdzie to gdzie zagrały trąbki myśliwskie”, bezpłatny dodatek do „Słowa” (wileńskiego), VIII 1929, s. 2. 
i zające, które dla schronienia się i pożywienia podchodzą do zabudowań, zagród, stodół i w bliskości ich się trzymaja, chwytane są masowo przez kłusowników za pomocą sideł lub za pomocą różnych innych podobnych środków ${ }^{18}$.

Z pewnością surowe zimy sprzyjały nielegalnemu polowaniu głównie na drobną zwierzynę.

Kłusownicy w Polsce nie koncentrowali się jedynie na drobnej zwierzynie. Już od lat dwudziestych wzrastała liczba nielegalnych polowań na różne gatunki dużych ssaków, należał do nich m.in. bardzo rzadko występujący przed 1939 r. łoś. Na te zwierzęta często kłusowali wszyscy mieszkańcy wsi. W Mamowie leżącym na Wileńszczyźnie w jednej ze stodół 20 IX 1928 r. policja odkryła przygotowane już partie mięsa ${ }^{19}$. Kilka dni później komendant posterunku w Jeziorach w powiecie grodzieńskim znalazł na pobliskim bagnie dogorywającego łosia. Do zwierzęcia kilkakrotnie strzelali kłusownicy, a wstrząśnięty publicysta pisał: „Biedne zwierzę niosło w sobie kilka kul i instynktownie kierowało się w stronę siedzib ludzkich, jak gdyby szukając pomocy"20. W części winiono za to właścicieli i dzierżawców łowisk, gdyż nie zabezpieczali i chronili ich odpowiednio. Jak ocenił Michał K. Pawlikowski, był to brak należytego obowiązku wobec kultury łowieckiej całego świata ${ }^{21}$. Niestety, problem ten nie dotyczył jedynie łosi.

Duże zwierzęta, często mocno okaleczone przez kłusowników, mimo bólu żyły jeszcze bardzo długo, a nawet przemieszczały się leśnymi, górskimi ostępami. Zdarzały się łosie, jelenie, wilki czy niedźwiedzie z wrośniętymi w ciało żelaznymi elementami kleszczy czy łańcuchów. We wrześniu 1933 r. przez Huculszczyznę wędrował tak okaleczony niedźwiedź. Jedynym wyjściem było zastrzelenie cierpiącego zwierzęcia. Jak napisano:

Żelazo o średnicy prawie pół metra, wagi kilkudziesięciu kg, zdruzgotało zupełnie przednią łapę niedźwiedzia, który mimo to zdołał wyrwać umocowany do żelaza łańcuch i podtrzymując żelazo pyskiem, przewędrował spory szmat ziemi. Wedle zeznań Hucułów, przeszedł niedźwiedź dzwoniąc łańcuchem, przez terytorium nadleśnictwa Hryniawa, być może ze sąsiedniej Rumunii. Silne wychudzenie misia, mierzącego w postawie stojącej zwyż $1,5 \mathrm{~m}$. świadczyło, że chodził z żelazem już pewien czas, nie mogąc, rzec prosta, zdobyć pożywienia. Zmiażdżona łapa, widoczna na zdjęciu, była już w stanie silnej gangreny. Kula nadleśniczego położyła kres męczarniom nieszczęśliwego zwierzęcia ${ }^{22}$.

18 APP, Akta Miasta Lwówek, 308, Odpis pisma okólnego Urzędu Wojewódzkiego Poznańskiego do Wszystkich Panów Starostów Powiatowych, Starostów Grodzkich i Prezydentów miast województwa poznańskiego, Poznań 1 II 1937.

19 R.D., Tequenie tosi, „Ochrona Przyrody” 1928, nr 8, s. 133.

${ }^{20}$ Ibidem.

${ }^{21}$ M.K. Pawlikowski Eosie gina..., „Gdzie to gdzie zagrały trąbki myśliwskie”, bezpłatny dodatek do „Słowa” (wileńskiego), IX 1930, s. 1.

${ }^{22}$ Archiwum Narodowe w Krakowie (dalej: ANK), Związek Opieki nad Zwierzętami w Krakowie (dalej: ZOZK), ZOZ/5, „Niedźwiedź ofiarą kłusowników” (wycinek prasowy z „Ilustrowanego Kuryera Codziennego" z dnia 22 VIII 1933), k. 55. 
Nielegalnie polujący chłopi najchętniej zabijali żubry, sarny czy dziki. To jednak było sporym przedsięwzięciem logistycznym i wiązało się z ryzykiem. Dlatego najczęściej nastawiano się jednak na mniejsze sztuki - zające, lisy, a nawet wiewiórki. Tylko między 8 a 11 I 1938 r. w powiatach kosowskim, stolińskim i łuninieckim, leżących w województwie poleskim, policjanci i gajowi zatrzymali na gorącym uczynku 8 kłusowników zakładających wnyki na zające i wiewiórki ${ }^{23}$. Warto zaznaczyć, że przebieg powyższych interwencji miał spokojny charakter, kłusownicy nie stawiali oporu, co nie stanowiło jednak reguły.

Duża liczba wspólnych akcji policji, gajowych i straży leśnej przebiegała dramatycznie. Wyjątkowa zuchwałość wykazywali kłusownicy dobrze znający teren, a przy tym zorganizowani w kilkuosobowe uzbrojone bandy. Niewiele pomagały obławy na takie grupy. Jedna z nich przeprowadzono w październiku 1927 r., kiedy policja i leśnicy ustalili, że w lasach bielińskich koło Brześcia znajduje się 7 lub 8 kłusowników. Na terenie lasu doszło do bitwy, zginął gajowy, a jeden z policjantów został postrzelony. Kłusownikom udało się przerwać blokadę i uciekli wraz z rannymi kolegami ${ }^{24}$. Zazwyczaj kłusownicy byli bardzo dobrze znani miejscowej policji czy gajowym, co jednak nie powstrzymywało ich agresji. Takie zdarzenie miało miejsce np. 11 I $1938 \mathrm{r}$. w lesie Karola Radziwiłła, kiedy to przy próbie zatrzymania kłusownicy Julian Łysiewicz i Piotr Poucha ze wsi Łachwy ostrzelali trzech gajowych ${ }^{25}$. Rozzuchwalenie sprawiało, że kłusownicy coraz mniej obawiali się także uzbrojonych właścicieli lasów. To właśnie kłusownicy 28 I 1931 r. zamordowali hr. Rudolfa Emila Baworowskiego, kiedy ten natkną się na nich w swoim lesie ${ }^{26}$. Hrabia został ograbiony ze sztucera, pieniędzy oraz papierosów.

W przedwojennym środowisku myśliwskim uzbrojony kłusownik miał opinię wyjątkowo bezwzględnego gangstera pozbawionego uczuć wobec zwierząt, ale i ludzi, w tym najbliższej rodziny. Józef Władysław Kobylański w 1927 r. przestrzegał, że tzw. zawodowy kłusownik to typ zabójcy-desperata. Uzbrojony bez wahania zabijał wszystkich, którzy próbowali go zatrzymać, zdeterminowany podejmował walkę, nie miał szacunku dla życia obcych ani swojego. Charakteryzowała go również nienawiść wobec osób, które zdemaskowały jego działalność. Jego frustrację i pragnienie nieobliczalnej zemsty miała potęgować konfiskata broni palnej. Jak pisał Kobylański:

${ }^{23}$ Archiwum Akt Nowych (dalej: AAN), Komenda Wojewódzka Policji Państwowej w Brześciu (dalej: KWPPB), 9, Meldunek sytuacyjny nr 16, Brześć n. Bugiem 21 I 1938, meldunek podpisany przez Naczelnika Urzędu Śledczego nadkomisarza J. Bobera, s. 2, k. 39.

${ }^{24}$ Krwawa bitwa z ktusownikami. Gajowy zbity - posterunkowy ranny, „Polska Zbrojna” 1927, nr 292, s. 3.

${ }^{25}$ AAN, KWPPB, 9, Meldunek sytuacyjny nr 15, Brześć n. Bugiem 20 I 1938, meldunek podpisany przez Naczelnika Urzędu Śledczego nadkomisarza J. Bobera, s. 2, k. 42.

${ }^{26}$ M. Piątkowska, Życie przestepcze w przedwojennej Polsce. Grandesy, kasiarze, brylanty, Warszawa 2012, s. 172-174. 
Kłusownik, który raz zapałał zemsta, to furiat i szaleniec. Morduje upatrzoną ofiarę nawet $\mathrm{w}$ kościele lub przy stole rodzinnym, strzelając wieczorem przez zamknięte okno: zabiera dzieciom ojca i żywiciela bez żadnego wzruszenia. Rodzonego ojca, brata czy krewniaka, przyjaciela czy znajomego lub mieszkańca tej samej wsi, położy wszystkich z równie lekkim sercem trupem, gdyby mu chcieli zabrać jego fuzję lub stanąc zaporą w niecnych jego praktykach ${ }^{27}$.

Kategoria uzbrojonego, zdeterminowanego i bezwzględnego dla ludzi i zwierząt kłusownika doczekała się w końcu lat trzydziestych swojej nazwy. Adam Rzewuski określił go jako „rubszyca” - człowieka niemal nieprzerwanie walczącego ze strażą łowiecką ${ }^{28}$. Jeśli hardy i strzelający do „wszystkiego, co żyje”, z broni palnej „rubszyc” budził strach, to nieuzbrojony i skrycie działający kłusownik-wnykarz wywoływał jeszcze większą pogardę. $\mathrm{W}$ opinii leśników i myśliwych skryty i sprytny wnykarz czynił nawet większe spustoszenie wśród zwierząt niż uzbrojony „rubszyc”. Dlatego też zgodnie twierdzono, iż „kłusownik-wnykarz nie zasługuje na miano człowieka” ${ }^{29}$. Wnykarz układający w lesie zakamuflowane rozmaite, proste lub wymyślne, pułapki był zaprzeczeniem myśliwego. Uważano, że wnykarze to kłusownicy „o marnych duszach”, którzy skrycie nieśli śmierć długo konającej zwierzynie. Jak wielka była to plaga, świadczyły przypadki ogromnego zapotrzebowania na drut, z którego wykonywano wnyki, a który kupowano w sklepach $\mathrm{w}$ prowincjonalnych miasteczkach ${ }^{30}$.

Mimo zaangażowania policji w walkę z kłusownictwem wygłaszano opinie, że wysiłki i środki sa niewystarczające. W publicystyce związanej z myślistwem pojawiły się głosy, że jeśli policja nie otrzyma odgórnych rozkazów, aby zintensyfikować walkę z kłusownictwem, to degradacji ulegnie kultura myśliwska, a życie właścicieli terenów łowieckich będzie ciagle zagrożone ${ }^{31}$. Rozczarowany brakiem sukcesów na tym polu poczuł się również komendant główny policji. Generał bryg. Kordian Zamorski w listopadzie 1937 r. pisał:

Szkodnictwo to nie znajduje na ogół dostatecznego przeciwdziałania ze strony policji. Nieliczne wyjątki więcej energicznego tępienia kłusownictwa potwierdzają tylko regułę, a w większości wypadków należy je przypisać wyłącznie zamiłowaniom myśliwskim kierownika danej jednostki policyjnej. Gdzie tych zamiłowań nie ma, tam walka z kłusownictwem, wbrew oczywistym interesom Państwa i wbrew obowiązkom policji, idzie bardzo opieszale, albo wcale jej nie $\mathrm{ma}^{32}$.

${ }_{27}$ J.W. Kobylański, W obronie użytecznej zwierzyny łownej, nakładem autora, Przemyśl 1927, s. 53.

${ }^{28}$ Wnyki i sidta. Echa towieckie, „Echa Leśne” 1937, nr 3, s. 42.

${ }^{29}$ Łowiectwo a lasy państwowe. Echa łowieckie, „Echa Leśne” 1931, nr 4, s. 6.

${ }^{30}$ B. Zarzycki, Głosy na czasie. Zastraszajace zjawisko, „Echa Leśne” 1937, nr 44, s. 930.

31 A.S.Ch., Zajście z ktusownikiem, „Łowiec” 1931, nr 3, s. 48.

32 AAN, KGPP, 1825, „Kłusownictwo - zwalczanie”, pismo Komendanta Głównego [Policji] gen. bryg. [Kordiana] Zamorskiego do wszystkich Komendantów Wojewódzkich Policji, Warszawa 24 XI 1937, s. 1, k. 4. 
W piśmie komendant określał kłusowników jako morderców, którzy nie przestrzegają żadnych zasad, w tym okresu godowego zwierząt. Wśród narzędzi zbrodni Zamorski wymieniał wnyki, sidła, potrzaski i trutki. Najmocniej jednak podkreślał niebezpieczeństwo posiadania przez kłusowników broni palnej. Jak pisał: „Posiadanie jej bowiem jest często podnietą do popełniania innych przestępstw, nie tylko kłusownictwa"33. Jak podawał Zamorski we wspomnianym piśmie do komendantów policji w Polsce, tylko w ciagu 9 miesięcy w 1935 i $1936 \mathrm{r}$. policja skonfiskowała 26598 sztuk nielegalnie posiadanej broni myśliwskiej.

Kłusownicy korzystali nie tylko z broni i amunicji myśliwskiej. Pozyskiwali broń przez pośredników z jednostek wojskowych. W maju $1936 \mathrm{r}$. żandarmeria wykryła w stacjonujacym w Tarnowskich Górach 11 Pułku Piechoty kradzież 30 karabinowych naboi. W toku śledztwa okazało się, że strz. Władysław Mstowski i strz. Władysław Kucharz dostarczyli amunicję kłusownikowi Janowi Kucharzowi, bratu Władysława. W raporcie żandarmerii stwierdzono, że Jan Kucharz posiadał bezprawnie wojskowy karabin, z którego nielegalnie polował na sarny ${ }^{34}$. Zdarzało się także, że kłusownicy mieli pozwolenie na broń myśliwską. Tak było w przypadku Jana Stromlewskiego z Drzonowa, wsi leżącej w województwie pomorskim. Jego kłusowanie nie wynikało z biedy, posiadał 140 morgów ziemi $(78,4 \mathrm{ha})^{35}$. To dowód na to, że w kłusownictwie uczestniczyły osoby o różnym statusie majątkowym.

Kłusownictwo stanowiło zazwyczaj dodatkową formę zarobkowania, jednak policyjne śledztwa odnotowywały tzw. zawodowych kłusowników, dla których uprawiany proceder był podstawową i jedyna pracą. W styczniu $1939 \mathrm{r}$. komendant posterunku w Kamionce zawiadamiał komendanta powiatowego policji w Lubartowie, że zawodowemu kłusownikowi Czesławowi Łaszewskiemu został zatrzymany karabin, a upolowaną sarnę w lesie Aleksandra Zamoyskiego zwrócono hrabiemu ${ }^{36}$.

Z pewnością biedniejszym kłusownikom pozbawionym broni palnej pozostawały tradycyjne sposoby, w których najważniejszą rolę odgrywały choćby wnyki. Nie zawsze były one zakładane w lesie, czasami rozmieszczano je de facto na terenie wsi, choćby na niezalesionych dobrach kościelnych. W $1937 \mathrm{r}$. rodzina Roszaków ze wsi Gębice koło Mogilna zakładała sidła na terenie łowieckim należącym do tutejszego proboszcza. Pozyskiwała w ten sposób bażanty i zające. Roszakowie wykazywali się zresztą przy tym dość dużym sprytem, ponieważ swoje przedsięwzięcia organizowali w dni świąteczne,

33 Ibidem.

${ }^{34}$ Wojskowe Biuro Historyczne (dawne Centralne Archiwum Wojskowe), I. 300.51.267, Dowództwo Żandarmerii, Sprawozdanie z przestępczości na terenie OK. IX za m-c maj 1936 r. z 25 VI 1936, s. 5.

${ }^{35}$ Grzybowski, Podłowczy na pow. Toruński, Kłusownictwo w jasny dzień. Z pola i kniei, „Myśliwy” 1938, nr 2, s. 28.

${ }^{36}$ APL, KPPPL, 175, Zwalczanie kłusownictwa, pismo z 30 I 1939. 
zazwyczaj podczas kościelnych nabożeństw ${ }^{37}$. Pomysłowość mieszkańców niektórych wsi, gdzie prawie wszyscy uprawiali kłusownictwo, nie znała granic. W styczniu 1938 r. Mieczysław Zawadzki, podkomisarz Policji Państwowej z Przeworska, odkrył, że w okolicznych wioskach przed domami ustawiano jodły i świerki, które wcześniej były świątecznymi choinkami. W środku drzewek znajdowały się specjalnie zamontowane pułapki, w które wpadały liczne kuropatwy ${ }^{38}$. Kłusownicy stosowali nie tylko różnego rodzaju oryginalne i okrutne sposoby chwytania zwierząt. Dużą wagę przywiązywali do dobierania odpowiednich aromatów, które były pozbawione ludzkiego zapachu: „Aby zwierzyna nie zwietrzyła człowieka, kłusownik zakłada sidła w rękawiczkach, którymi uprzednio dotykał żywicy lub mchu mokrego" ${ }^{39}$. To sprawiało, że do wnyków, pętli i sideł dostawało się jeszcze więcej zwierząt.

Pamięć o pańszczyźnie, szczególnie żywa w Galicji czy na Kresach Wschodnich, dopełniała poczucie krzywdy i niesprawiedliwości. Chłopi z zazdrościa obserwowali częste polowania ziemian, które przeważnie kończyły się obfitym połowem. Nie do odróżnienia było dla nich legalne korzystanie z darów lasu od ich nielegalnych eskapad. Widowiskowe polowania dworskie, w których miejscowi chłopi uczestniczyli choćby jako nagonka, budziły naturalną zazdrość z powodu zarówno widoku upolowanej zwierzyny, jak i obfitości uczt myśliwskich organizowanych przy wielkich ogniskach. Obraz świetnie ubranych, uzbrojonych, zadowolonych ze swoich dokonań „panów” na tle asystujących chłopów tylko potwierdzał, że stosunki feudalne nie należały do przeszłości ${ }^{40}$.

Iskra zapalna przeciw władzy państwowej bywały też tzw. polowania reprezentatywne, w których brali udział krajowi dostojnicy państwowi, jak Ignacy Mościcki, Edward Rydz-Śmigły (nota bene mierny myśliwy), a także wysocy ranga goście z zagranicy, jak Hermann Göring czy regent węgierski Miklós Horthy. W listopadzie 1925 r. policja polityczna sprawdzała, czy w okolicach Opola Lubelskiego rzeczywiście rozgłaszano pogłoski, że w Warszawie bezrobotni mieli urządzać manifestacje przeciwko polowaniom prezydenta Stanisława Wojciechowskiego ${ }^{41}$. Chłopi niekoniecznie rozumieli, że poza myśliwska pasją i przyjemnością uczestników polowania służyły też specyficznej grze dyplomatycznej. Podczas polowań dyskutowano o rozmaitych sprawach, podejmowano polityczne czy społeczne tematy. Do prostych i niepiśmiennych mieszkańców wsi bardziej przemawiały zdjęcia z ówczesnej prasy, na których uśmiechnięci i zadowoleni politycy czy hrabiowie dumnie prężyli się przy zastrzelonych niedźwiedziach, wilkach, dzikach czy lisach.

\footnotetext{
37 S. Łukowicz, Wnykarstwo w Święta Bożego Narodzenia, Z pola i kniei, „Myśliwy” 1938, nr 2, s. 63-64.

${ }^{38}$ M. Zawadzki, podkomisarz PP, Choinka pułapka na kuropatwy, „Na Posterunku” 1938, nr 18 , s. 418.

${ }^{39}$ Z. Julski, aspirant PP, Kłusownictwo, „Na Posterunku” 1935, nr 38, s. 624.

${ }^{40}$ W. Mich, Ideologia polskiego ziemiaństwa 1918-1939, Lublin 2000, s. 133.

${ }^{41}$ APL, Okręgowy Urząd Policji Politycznej w Lublinie, 52, Pismo z 14 XI 1925, k. 9.
} 
Niezamożni mieszkańcy poleskiej prowincji odławiali także masowo żółwie, które za niewielkie pieniądze (w 1938 r. 50 gr za sztukę) sprzedawali handlarzom. Spowodowało to drastyczny spadek populacji tych zwierząt w tutejszych rzekach, o czym w styczniu 1939 r. alarmowała prasa ${ }^{42}$. Celem nielegalnych polowań nie było tylko pozyskanie mięsa, w przedwojennej Polsce wyłapywano również różne gatunki rzadkiego już za granicą (głównie w Niemczech) ptactwa. W 1933 r. na terenie gminy Ryczów, leżącej w powiecie oświęcimskim, miejscowi chłopi wspólnie z handlarzami przyjeżdżającymi z Górnego Ślaska masowo chwytali szczygły, gile, a także makolagwy. Ptaki te prawdopodobnie transportowano do Niemiec ${ }^{43}$. Nie tylko na zwierzęce okazy, w formie żywej czy też martwej, był popyt za granica. Powodzeniem cieszyły się także zwierzęce skóry - surowe pojawiały się na lokalnych bazarach. Tego rodzaju proceder wymagał dużo lepszego zorganizowania. W lipcu 1934 r. jedna z takich grup przestępczych zlikwidowała warszawska policja. Na tutejszym targu zatrzymano nie tylko paserów zwierzęcych skór, ale również dostawców. W toku śledztwa okazało się, że zdarte, surowe skóry z upolowanych nielegalnie zwierząt w Puszczy Białowieskiej do stolicy przywoził Szymon Subota, gajowy z Białowieży (sic!), a pomagali mu dwaj bratankowie ${ }^{44}$. Kłusownicze inklinacje osób, których zadaniem było m.in. ściganie tego rodzaju przestępstw, z pewnością nie pomagały w skuteczniejszej walce z tym zjawiskiem.

Dla polującego z pasją ziemiaństwa deficyt wyżywieniowy stanowił problem abstrakcyjny. Polowano nie dla mięsa, ale by afirmować życie ${ }^{45}$. Dla epigonów rycerstwa wyruszenie w knieje było kontynuacją tradycji polowań ojców. W tych kręgach wciąż utrzymywało się przekonanie, że każdy szlachcic rodzi się myśliwym ${ }^{46}$. Wchodzenie na teren łowiecki ziemiaństwa chłopów kłusowników traktowano jako przekroczenie niepisanej granicy, odwiecznego dystansu, który dzielił dwie różne warstwy społeczne. Kłusowników uznawano za złodziei próbujących kraść ziemiański inwentarz zwierzęcy, szlachecki rezerwuar, pogardzano nimi. Wyśmiewano słabe uzbrojenie chłopów kłusowników, a także fakt, że towarzyszyły im nierasowe psy $^{47}$. Pozornie więc rzeczywistość kłusowniczą od myślistwa oddzielał mur nienawiści. Co ciekawe, jednak te dwa odmienne światy czasem się spotykały. Na Kresach Wschodnich to właśnie miejscowi kłusownicy pełnili rolę przewodników dla polujacych w weekendy inteligentów z Lwowa, Grodna czy Wilna. Jak wspominał

\footnotetext{
${ }^{42}$ Żótwie na Polesiu zagrożone, „Polska Zbrojna” 1939, nr 8.

${ }_{43}(\mathrm{Wu})$, Barbarzyńskie praktyki chłopstwa wobec ptactwa $i$ drobnych zwierzat, „Ilustrowany Kuryer Codzienny" 1933, nr 18, s. 6.

${ }^{44}$ Obdzierali ze skóry zwierzęta w Białowieży. Wykrycie niezwyktej afery ktusowniczej, „Ostatnie Wiadomości Krakowskie" 1934, nr 189, s. 1.

${ }^{45}$ M.J. Łozińscy, Życie codzienne arystokracji, Warszawa 2013, s. 210.

${ }^{46}$ M. Łozińska, W ziemiańskim dworze. Codzienność, obyczaje, święta, zabawy, Warszawa 2011, s. 319.

${ }^{47}$ J.W. Kobylański, op. cit., s. 33.
} 
Michał Kryspin Pawlikowski, prozaik, krytyk literacki i dziennikarz „Słowa Wileńskiego", to kłusownicy byli prawdziwymi gospodarzami Puszczy Hołubickiej. Korzystający z ich usług Pawlikowski określał tę grupę jako „leśnych ludzi”. Tego rodzaju eufemizm miał swoje uzasadnienie: „leśni ludzie” byli dla niedzielnych myśliwych z miasta wcieleniem westernowych postaci, nieprzewidywalnymi traperami skutecznie tropiącymi zwierzynę, mającymi świetną orientację w terenie oraz w meteorologii. Dla Pawlikowskiego stanowili swoiste studium. Poza gruboskórnością czy cynizmem, a także rzadkim uczestniczeniem w kościelnej czy cerkiewnej mszy, o czym wspominał dziennikarz „Słowa Wileńskiego”, „gajowi-kłusownicy” byli ludźmi wierzącymi w różnego rodzaju wróżby czy przesądy. Dla Pawlikowskiego świat, mentalność oraz charakter kłusowników i myśliwych nie różniły się. Jak pisał:

Kłusownik jest myśliwym, a myśliwy jest poeta [...]. Lecz nie tylko poetą jest kłusownik białoruski! Jest traperem i naturalista. Zna szlaki i obyczaje dzikiego zwierza. Dawniej wypatrywał i „okładał” barłóg niedźwiedzia, dziś zasadza głuszca lub tropi wilka. Zna właściwości ziół tajemniczych. Przepowiada pogodę, umie też zapewne zamawiać i czarować. Czyta w puszczy jak w otwartej księdze, „która głucha dla mieszczan, mnóstwem głosów szepcze mu do ucha”48.

Ciekawe jednak, że Michał Kryspin Pawlikowski nabrał dziwnej sympatii do kłusowników po upływie kilkunastu lat. Jeszcze w kwietniu 1929 r. na antenie wileńskiego radia edukował społeczeństwo, że między kłusownictwem a myślistwem przebiega wyraźna granica moralna. Według Pawlikowskiego jednakową niechęć budzili tzw. leśni pętlarze, kupujący od kłusowników zwierzynę restauratorzy, handlarze poszukujacy zwierzęcych skór oraz domowe gosposie nabywajace okazyjnie na targach kuropatwy. $\mathrm{Na}$ antenie radia Pawlikowski grzmiał: „ci wszyscy, którym my, myśliwi, wypowiadamy walkę bezwzględna - aż do skutku" ${ }^{49}$. Metody prowadzenia niektórych wypraw myśliwskich czasem nasuwały skojarzenie z kłusownictwem. Niektóre formy myślistwa bardziej przypominały pełne sadyzmu dręczenie, prześladowanie i zabijanie w mękach zwierząt, nie miały zaś nic wspólnego z etyką łowiecka, na którą tak chętnie powoływali się uprawiający łowiectwo. Dotyczyło to przede wszystkim polowania par force, kiedy używano koni wraz z psami gończymi. W trakcie polowania ścigano zwierzę tak długo, dopóki nie skonało ze zmęczenia ${ }^{50}$. Była to ulubiona metoda polowania choćby hr. Alfreda Potockiego z Łańcuta.

${ }^{48}$ S. Badeni, Szczęśliwe dni i inne wspomnienia myśliwskie Janusza Jędrzejewicza i Michała Kryspina Pawlikowskiego, wybór, oprac., wstęp i przypisy J.A. Radomski, Warszawa 2011, s. 221.

${ }^{49}$ Społeczne $i$ państwowe znaczenie towiectwa (odczyt dla nie myśliwych wygtoszony przez radio wileńskie), „Gdzie to gdzie zagrały trąbki myśliwskie”, bezpłatny dodatek do „Słowa” (wileńskiego), IV 1929, s. 1.

${ }_{50}$ Dwudziestolecie międzywojenne..., s. 52. 
Z niebezpieczeństwa ewolucji myślistwa w kłusownictwo zaczęto zdawać sobie sprawę dość szybko. Już w 1923 r. Władysław Janta-Połczyński uznał, że zdemoralizowanego myśliwego bez zasad charakteryzują tylko i wyłącznie polowania z chciwości i dla rekordu. Tak zwany myśliwy nie przestrzegał również okresu ochronnego zwierzyny. Do najgorszego w jego opinii należał typ „niedzielnego myśliwego”. Pisał, że to typ „myśliwego, który strzela jak bolszewik do każdej napotkanej zwierzyny. Tego typu łowczemu chodzi wyłącznie o zabicie jak największej liczby zwierząt i obwieszenie ścian swojego domu trofeami" ${ }^{1}$. Janta-Połczyński przypominał, że zwierzę powinno być upolowane po trudzie, po żmudnym tropieniu i bez zadawania mu zbędnych cierpień. Dyskusje na temat etycznych polowań, które wyraźnie odróżniały je od tak potępianego wśród myśliwych kłusownictwa, toczono również w kolejnych latach. Dziesięć lat po ukazaniu się książki Janta-Połczyńskiego Adam Starzeński w piśmie „Łowiec” apelował o humanitarne polowanie, tak by zwierząt nie skazywać na powolne konanie w mękach. Pisał: „My, zwierzyna «litości, litości» wołamy, o Człowiecze. A w nekrologach naszych, jeżeli już taki los przypadał nam w udziale, pisz o Człowiecze: «nagle i niespodziewanie», a nie «po długich i ciężkich cierpieniach»" "52. Dla osób dumnych z przynależności do stanu myśliwskiego zarzuty o kłusownictwo stanowiły infamię. W przypadku leśników wspierających polowania myśliwych takie oskarżenia nie tylko niszczyły ich reputację, wiązały się także z poważnymi konsekwencjami zawodowymi. Starano się je szybko wyjaśniać. Kiedy podejrzewano, że to insynuacje, dyrekcja Lasów Państwowych broniła swoich pracowników z niezwykłym poświęceniem, jak przodownika leśnego Kielczewskiego z leśnictwa w Błotkowie, z nadleśnictwa Leszno, którego przy okazji polowania posądzono o skryte zabicie sarny, a leśniczego Kazimierczaka z tego samego leśnictwa i nadleśnictwa o zezwolenie na strzelanie do jastrzębi. Dyrekcja podkreśliła, że prokuratura swoje śledztwo skierowała na niewinne osoby. Szefostwo Lasów Państwowych wspominało, że pracownicy ci pełnią swoją służbę z oddaniem, rzetelnie i dobrze znają przepisy. Co ciekawe, w niefortunnym polowaniu, które w pewnym momencie grawitowało w stronę kłusownictwa, uczestniczył również prokurator formułujący swoje inkryminacje (sic!). Jak pisał dyrektor Lasów Państwowych:

Nie godzę się na ukaranie leśniczego Kazimierczaka, tym bardziej, że muszę mieć na uwadze wzmiankę, poczyniona przez tego leśniczego co do udziału Pana Podprokuratora w polowaniu tegoż dnia 18-go lipca 1926. (karta 13), a na którą p. Podprokurator zupełnie nie zareagował. Winien zaś był zdaniem moim zareagować przez zrzeczenie się prowadzenia dochodzeń i ewentualne wystapienie w roli świadka, gdyż Podprokuratorem, który brał udział w polowaniu, był właśnie p. Podprokurator Owczarski ${ }^{53}$.

\footnotetext{
51 W. Janta-Połczyński, Estetyka łowiectwa z ilustracjami, Poznań 1923, s. 9-10.

52 A Starzeński, „Litości! Litości”, „Łowiec” 1933, nr 1, s. 5.

${ }_{53}$ APP, DLPP, 282, Pismo Dyrekcji Lasów Państwowych w Poznaniu z 26 VIII 1927, s. 5.
} 
Z pisma wynikało, że w feralnym polowaniu uczestniczyła elita Leszna. Prokuratura posądzała o kłusownictwo nie tylko pracowników Lasów Państwowych, ale także jednego z biorących w nim udział lekarzy.

Mimo że propaganda i lobby myśliwskie w II Rzeczypospolitej były niezwykle silne, wpływowe i powiązane z obozem władzy, w latach trzydziestych coraz częściej pojawiała się krytyka myślistwa. Sugestie, że jest ono na równi z kłusownictwem szkodliwe dla lasu i jego mieszkańców, odpierano z zaciekłościa. Postapił tak Kazimierz Świderski, który poczuł się urażony słowami M.D., jednego z czytelników „Wiadomości Turystycznych”, który uznał myślistwo za proceder zbrodniczy. Świderski oskarżycielowi myślistwa dawał jasno do zrozumienia, że krytyka w obliczu powiazania myślistwa z wpływowymi politykami w kraju i ich potężna protekcja jest zupełnie bez szans: „Zaatakowana przez M.D. Międzynarodowa Rada Łowiecka nic a nic nie straciła na swoim znaczeniu, a my, myśliwi polscy pamiętamy i dumni z tego jesteśmy, że uroczystości z jej Kongresem związane odbywały się pod wysokim protektoratem Najdostojniejszych w naszym Państwie osobistości" ${ }^{4}$. Pojedynczy głos w żaden sposób nie był w stanie zdyskredytować przedwojennego myślistwa. Tym bardziej nie mógł przekonać, że granice między myślistwem a kłusownictwem są umowne.

Nigdy na podobną opinię nie zdecydowały się organizacje broniące zwierząt. Zdarzało się jednak, że piętnowały myśliwych. W środowiskach obrońców zwierząt uznawano, że legalne polowania, w trakcie których wybija się rzadka i chronioną zwierzynę, są barbarzyńskie. Największa fala publicznej krytyki wobec myślistwa rozpętała się w $1931 \mathrm{r}$. W styczniu tegoż roku w lasach pszczyńskich książę Karol Mikołaj Radziwiłł zabił będące pod ochroną dwa żubry. W tym samym czasie hr. Alfred Potocki w nadleśnictwie Sołotwina ustrzelił niedźwiedzicę wraz z młodym. W Sprawozdaniu z działalności Państwowej Rady Ochrony Przyrody w roku 1931 prof. Władysław Szafer przypomniał, że te czyny zostały w prasie polskiej surowo potępione i określone jako niemające nic wspólnego z łowiectwem ${ }^{55}$. W $1925 \mathrm{r}$. w powiecie rybnickim, w gminie Lyski wydzierżawiono tereny pod polowanie osobie, która za kłusownictwo kilka lat wcześniej przebywała $\mathrm{w}$ więzieniu ${ }^{56}$. Takie wydarzenia publicznie potępiano, wywoływały protesty, dla chłopów kłusowników stanowiły jednak sygnał, że niewiele różni ich od polujących hrabiów czy książąt. Dzierżawienie terenów byłym kłusownikom utwierdzało nielegalnie polujących w poczuciu, że za takie postępowanie nie ponosi się żadnych konsekwencji.

Duże nadzieje w likwidacji lub ograniczaniu kłusownictwa wiązano z prawem łowieckim ustanowionym 3 XII 1927 r. przez prezydenta RP (DzU 1927,

\footnotetext{
${ }^{54}$ K. Świderski, Atak furii, „Łowiec” 1934, nr 1-12, s. 96.

55 W. Szafer, Sprawozdanie z działalności Państwowej Rady Ochrony Przyrody w roku 1931, nr 31, Kraków 1932, s. 13.

${ }^{56}$ APK, UWSWR, 763, Odpis pisma z 10 XII 1925, k. 20.
} 
nr 110). Rozporządzenie ściśle regulowało ochronę czasową bądź całoroczna zwierząt, a także określało kary za niestosowanie się do niej. Dokument zabraniał również używania „kłusowniczego arsenału” (art. 41). Nie wolno więc było łowić za pomocą trutek, wnyków, samostrzałów, dołów - ostrokołów, lepu, ziarna rozmoczonego w spirytusie, żelaznych potrzasków, sideł czy też wszelkiego rodzaju pułapek ${ }^{57}$. Niestety nic nie wskazuje na to, że wprowadzenie prawa łowieckiego w jakikolwiek sposób poprawiło sytuację. Dużą rolę odegrało przy tym negatywne nastawienie do ustawy niektórych chłopskich działaczy politycznych. Najbardziej krytyczne stanowisko zaprezentowało Polskie Stronnictwo Ludowe „Wyzwolenie”. W styczniu 1928 r. Józef Putek zrównywał wydany dekret prezydencki z filozofia jednej z amerykańskich sekt, która - jak pisał - zabraniała zjadania i zabijania zwierząt ${ }^{58}$. Nie zachęcało to chłopów do porzucenia kłusowniczych zwyczajów.

W pokonanie kłusownictwa nie wierzyło również środowisko przedwojennych leśników. Pewna nadzieja tliła się jednak w nieokreślonej przyszłości, kiedy między wsią a leśnikami miały zawiązać się serdeczniejsze relacje ${ }^{59}$. Oczekiwania wiązano z najmłodszą generacja. W końcu lat trzydziestych pojawiały się różne koncepcje resocjalizacji nielegalnie polującej młodzieży. Jeden z pomysłów wskazywał, że młodzi kłusownicy mogą zamienić się w prawdziwych myśliwych. Jan Bobkowski w sierpniu 1937 r. sugerował, aby dla wiejskiej młodzieży obniżyć cenę zakupu legalnej broni i opłat za wystawienie karty łowieckiej ${ }^{60}$. Taka propozycja natychmiast spotkała się z polemika. Edward Owczarek twierdził, że szkolenie łowieckie wiejskiej młodzieży nie ma szans powodzenia. Barierę tworzyła przede wszystkim ogromna nieufność mieszkańców wsi ${ }^{61}$. Owczarek wnioskował, że najprostsze rozwiązanie stanowi zwiększenie zatrudnienia wiejskiej młodzieży.

Kłusownictwo było traktowane dosyć pobłażliwie przez ówczesny wymiar sprawiedliwości, sprawcy często unikali jakichkolwiek konsekwencji. Tak zdarzyło się w maju 1934 r., kiedy góral Władysław Gasienica-Giewont, w którego plecaku policja odnalazła złowione w miejscowym potoku pstragi w Polsce obowiazzywał zakaz ich połowu - został jedynie spisany, a następnie zwolniony do domu. Być może na taką decyzję wpłynęły okoliczności, albowiem towarzysz zatrzymanego, Stanisław Korona został wcześniej zastrzelony. Ścigajacy kłusowników zakopiański policjant pomylił złodziei ryb ze sprawcami włamania do jednego z miejscowych domów ${ }^{62}$. Wydaje się, że dość

${ }^{57}$ Prawo towieckie. Rozporzadzenie Prezydenta Rzeczypospolitej z dnia 3 grudnia 1927 r. o prawie towieckim (Dz. Ust. Nr. 110), Warszawa 1928, s. 27.

58 J. Putek, Opiekunowie wilków, dzików i niedźwiedzi, „Wyzwolenie” 1928, nr 15, s. 8.

59 J. Krawczyk, Lasy Drugiej Rzeczpospolitej w dawnych zapisach prasowych. Wydarzenia zwykte i niezwykte, Warszawa 2010, s. 63.

60 J. Bobkowski, Czy mam rację?, „Echa Leśne” 1937, nr 32, s. 690.

${ }^{61}$ E. Owczarek, Szkolenie łowieckie młodzieży, „Echa Leśne” 1937, nr 44, s. 930.

62 W., Okropna pomytka policjanta, „Polska Zbrojna” 1934, nr 122, s. 6. 
łagodna kara spotkała również rodzinę Stromlewskich. W toku dochodzenia okazało się, że w kłusownictwie nie uczestniczył jedynie, opisany już, bogaty gospodarz Jan. Wszystkich, którzy brali udział w tym procederze od dłuższego już czasu, sąd w Wąbrzeźnie skazał na 150 zł grzywny, a w razie jej niezapłacenia na bezwzględne 30 dni aresztu ${ }^{63}$. W czerwcu 1934 r. na 3 lata więzienia został skazany Julian Kowalski, niebezpieczny i uzbrojony kłusownik, który bezprawnie polował w lasach koło Krynicy (niedaleko Puszczy Białowieskiej). Nie tylko posiadał on nielegalnie broń, ale także straszył nia próbujących go zatrzymać gajowych ${ }^{64}$. Dość ulgowo polskie sądy traktowały również członków kłusowniczych zorganizowanych grup przestępczych, którzy trafiali przed oblicze wymiaru sprawiedliwości. 15 III 1934 r. krakowski sąd skazał 5 kłusowników na karę 6 miesięcy więzienia i utratę praw obywatelskich na 3 lata $^{65}$. Sąd orzekł taki sam wymiar kar również dla Władysława Pomiernego - herszta, który groził zastrzeleniem ścigających grupę gajowych.

Najsurowsze wyroki, jakie wydano na kłusowników w II Rzeczypospolitej, zapadły w białostockim sądzie okręgowym we wrześniu $1936 \mathrm{r}$. Na ich mocy skazano na dożywocie Stefana Puchalskiego i Kazimierza Wróblewskiego, którzy nie tylko nielegalnie polowali na zwierzęta, ale zamordowali egzekutora skarbowego, a także woźnicę, który go przewoził. W toku śledztwa ustalono, że Wróblewski w 1933 r. pozbawił życia miejscowego gajowego. Kilka lat wcześniej, kiedy wiedziano jedynie, że gajowy zaginą, Wróblewski ubiegał się o jego posadę (sic!). Oprócz morderców na 12 i 8 lat więzienia skazano jeszcze Hnyszkę i Burzyńskiego, mężczyzn, którzy nakłonili Puchalskiego i Wróblewskiego do zabójstwa egzekutora skarbowego i woźnicy ${ }^{66}$. Od tego wyroku odwoływał się prokurator, a także pozostali skazani, żądając dla Hoszki wyższej kary, z wyjątkiem Wróblewskiego, który zaakceptował decyzję sądu. Być może wymierzanie względnie niskich kar kłusownikom przez polskie sądy wypływało jeszcze z jednej przyczyny: „Przyjezdni inteligenci: leśnicy, sędziowie i urzędnicy postrzegali chłopów jako ofiary systemu historii, stąd wyroki przedwojennych sądów w sprawach o kradzież i kłusownictwo bywały często łagodne”"67. Sądy jakby zapominały, że groźby wobec gajowych i leśniczych, którzy wykazywali gorliwość w tępieniu kłusownictwa, były codziennością. Zastraszano też żony, dzieci i krewnych osób chroniących leśne dobra. Te sprawy prawie nigdy nie trafiały na sądową wokandę. Rozzuchwaleni bandyci przechodzili od słów do czynów. Dotkliwe pobicia były kolejnym

\footnotetext{
${ }^{63}$ Do artykułu „Ktusownictwo w jasny dzień”- str. 28 nr 2/38 „Myśliwego”, Z pola i kniei, „Myśliwy” 1938, nr 2, s. 64.

${ }^{64}$ Kłusownik skazany na 3 lata więzienia, „Ostatnie Wiadomości Krakowskie” 1934, nr 158, s. 2.

${ }_{65}$ Banda ktusowników przed sqdem karnym, „Ostatnie Wiadomości Krakowskie” 1934, nr 74, s. 6.

${ }^{66}$ Kłusownik morderca. Sad skazat go na 12 lat więzienia, „Ostatnie Wiadomości Krakowskie" 1936, nr 271, s. 2.

${ }^{67}$ M. Piątkowska, op. cit., s. 176.
} 
etapem polityki strachu wobec leśników i gajowych. Natychmiastowe ujęcie sprawców terroru należało do rzadkości. W lipcu 1938 r. „Tempo Dnia” informowało: „Odchodząc, zagrozili pobitym małżonkom krwawą zemsta w wypadku zawiadomienia o zajściu policji. Nie ulega wattpliwości, że napad ten podyktowany był zemstą szkodników lasowych za zbyt energiczne ich tępienie przez gajowego. Pościg za napastnikami nie doprowadził dotychczas do ich ujęcia" 68 . Nie wiadomo, ile tego rodzaju przypadków pobić czy gróźb karalnych w ogóle nie zostało zgłoszonych policji.

Orzeczone wyroki wymiaru sprawiedliwości wobec kłusowników nie satysfakcjonowały również głównego komendanta policji. W jego rozkazie (nr 724) widać było rozczarowanie przebiegiem rozpraw sądowych. Zamorski, który problem kłusownictwa traktował priorytetowo, domagał się od swoich podwładnych bacznego śledzenia procesów sądowych, żądał aktywnego udziału najlepszych funkcjonariuszy w sądach, w miarę możliwości zobowiązani oni byli do oskarżania zatrzymanych kłusowników ${ }^{69}$. Zamorski poświęcał tak dużo uwagi kwestii kłusownictwa, ponieważ sam niejednokrotnie uczestniczył w polowaniach.

Również urzędnicy podlegli starostom lub prezydentom miast mobilizowali policję do intensyfikacji walki z kłusownictwem. Chodziło w tym wypadku o grunta rolne, które znajdowały się w obrębie gmin miejskich lub którymi zarządzali miejscy urzędnicy. Do zmotywowania policji używano niekiedy kontrowersyjnych środków. Komendantom policji za wyjątkowe zaangażowanie oferowano specjalne zniżki w opłatach za uczestnictwo w polowaniach, szefowie posterunków policji uzyskiwali także dostęp do zastrzeżonych enklaw łowieckich. Koło Krakowa, w należącym do klasztoru oo. Kamedułów Mnikowie, specjalna, prawie dwuletnia zgodę na polowanie wydano dla Aleksandra Szczepańskiego, komendanta posterunku w Bronowicach Małych. $\mathrm{W}$ zamian za to Szczepański miał zintensyfikować ochronę zwierząt ${ }^{70}$. Po roku jednak zrzekł się on prawa do polowań na preferencyjnych warunkach. W piśmie do Zarządu Lasu Wolskiego czuł się rozczarowany, że na powierzonym mu terenie zdołał upolować jedynie 2 zajace i 7 kuropatw. $Z$ ubolewaniem pisał, że niepilnowany teren został wcześniej całkowicie przetrzebiony przez kłusowników ${ }^{71}$. Tego rodzaju inicjatywy nie mobilizowały policjantów. Nie przyczyniały się też do poprawy zagrożonego terenu.

Do końca istnienia II Rzeczypospolitej nie zahamowano kłusownictwa. W kwietniu 1938 r. KGPP w Warszawie opracowała mapę Polski, na której zaznaczono miejsca, gdzie rejestrowano tego rodzaju przestępstwa. Najwięcej przypadków kłusownictwa zanotowano w okolicach Włoszczowej, Garwolina,

\footnotetext{
${ }^{68}$ Nocny napad na mieszkanie gajowego, „Tempo Dnia” 1938, nr 189, s. 2.

${ }^{69}$ AAN, KGPP, 1825, Wyciag z rozkazu Kom. Gł. Nr 724 VI, k. 3.

${ }^{70}$ ANK, Ekspozytura Spytkowice (dalej: ES), Miejski Park i Ogród Zoologiczny w Krakowie (dalej: MPOZK), 29/1351/29, Pismo z 23 X 1936.

${ }^{71}$ Ibidem, Odpis pisma z 12 X 1937.
} 
Radomska, Bielska Podlaskiego, Koła, Konina, Kalisza, Żywca, Nowego Targu, Wadowic i Lublina; lepiej było w ówczesnym województwie pomorskim (za wyjątkiem okolic Włocławka), a także w zachodniej części Wielkopolski; najlepiej zaś na Kresach Wschodnich - w województwach wileńskim (z wyjątkiem okolic Oszmiana), nowogródzkim, wołyńskim, lwowskim, tarnopolskim, stanisławowskim (z wyjątkiem okolic Stryja) - stwierdzono tam nieliczne przypadki nielegalnego łowiectwa ${ }^{72}$. Kłusownictwo było obecne na przedmieściach Warszawy, Lwowa czy Krakowa, tu zabijano głównie drobna zwierzynę, a i kłusownicy nie zachowywali się tak zuchwale, jak na prowincji. Działali przeważnie nieuzbrojeni, posługiwali się przede wszystkim wnykami. Jednak, mimo aktywności straży leśnej, zwiększonej kontroli, zjawiska nie udawało się wyeliminować. Niestety, duże ośrodki z najdalszymi wsiami na Podolu czy Polesiu wciąż łączyły tradycje wnykarskie. Z goryczą o kłusowniczej rzeczywistości krakowskiego Lasku Wolskiego, chlubie miasta, w lutym 1933 r. w liście do lwowskiej redakcji czasopisma „Łowca” pisał inż. Witold Friedberg, kierownik Zarządu Lasu Miejskiego Las Wolski:

\begin{abstract}
Straż Leśna właśnie w tych dwóch obiektach [tj. ogrodzonych enklawach w górnej części przy lesie i tuż nad Wisła - R.K.], z braku dostępu nie może należycie dokonywać ochrony zwierzyny, wyhodowanej z dużym nakładem pracy i gotówki, podczas gdy wnykarze do wewnątrz przedostając się pomimo ogrodzenia maja doskonały teren działania pod osłoną ogrodzenia, zwłaszcza w nocy. Wzmożona ochrona zwierzyny konieczna jest tym bardziej w tej części obwodu ze względu, że wieś położona u stóp powyższych wzgórz, była niegdyś siedliskiem dziedziczonego kłusownictwa i wnykarstwa ${ }^{73}$.
\end{abstract}

Trudno zweryfikować, czy dane o skali kłusownictwa, napływajace ze wszystkich komend wojewódzkich do KGPP, były wiarygodne i wyczerpujące. Jeśli przyjać, że tak, to wnioski płynące z opracowanej mapy kłusownictwa na wiosnę 1938 r. w Polsce są szokujące. Największą liczbę omawianych przestępstw ujawniono na ziemiach rdzennie polskich, kłusownictwo rozwijało się także intensywnie w okolicach teoretycznie zamożniejszych, jak Koło, Konin czy Kalisz ${ }^{74}$. Najmniejszą liczbę przypadków nielegalnych polowań zanotowano na ziemiach, gdzie ludność polska, szczególnie na prowincji, stanowiła mniejszość, czyli w województwach wołyńskim, tarnopolskim, lwowskim czy stanisławowskim.

Z pewnością kłusownictwa nie można jednak utożsamiać z konkretną narodowością. Zestawienia, jakie otrzymała KGPP od komend prowincjonalnych, budzą też zastrzeżenia. Sporadyczne przypadki kłusownictwa odnotowane na terenach silnie zalesionych, jak okolice Leska, Przemyśla, Polesia czy

\footnotetext{
72 AAN, KGPP, 1825, Wypadki kłusownictwa. Mapa administracyjna Rzeczypospolitej Polskiej z dnia 1 IV 1938, k. 5.

${ }^{73}$ ANK, ES, MPOZK, 29/1351/29, List do redakcji lwowskiego czasopisma „Łowca” z 10 II 1933, s. 2-3.

${ }^{74}$ AAN, KGPP, 1825, Wypadki kłusownictwa..., k. 5.
} 
wschodnia część województwa nowogródzkiego, świadczyć mogą nie tyle o minimalnej skali tego zjawiska, ale o nikłej wykrywalności policji. Na wiejskich obszarach zamieszkiwanych przez ludność białoruską czy ukraińską panowała jeszcze większa „zmowa milczenia” wobec polskiej administracji. Współpracę z polską policją często traktowano nie jako akt lojalności wobec państwa, ale kolaborowanie z nieprzyjazną i obca władzą. Korzystali na tym kłusownicy, choć dla zwierząt ginacych $\mathrm{w}$ cierpieniach nie miało znaczenia, czy sa to polskie dubeltówki, ukraińskie wnyki, białoruskie sidła, czy litewskie sieci.

W przedwojennej Polsce kłusownictwo nie zostało znacząco ograniczone. Taki stan rzeczy miał kilka przyczyn. Społeczeństwa wiejskie były hermetyczne, obowiązywała zmowa milczenia, nie współpracowano z policja w ściganiu kłusowników. Właśnie dlatego komendant Policji Państwowej Zamorski w cytowanym już wcześniej piśmie z 24 XI 1937 r. bardzo dużą wagę przywiązywał do działań wywiadowczych. Mieszkańcy wsi pozostawali nieufni nie tylko w stosunku do policji, ale także właścicieli ziemskich i dóbr leśnych. Ewentualna zmiana wymagała poważnej edukacji na prowincji. Do tego wiodło nie tylko zbliżenie leśników i mieszkańców wiosek, potrzebne było współdziałanie środowisk ziemiańskich, chłopskich, a także wzrost zaufania do policji i miejscowych władz urzędniczych. Z pewnością kłusownictwo mogła zahamować poprawa sytuacji społeczno-gospodarczej wsi. Niewykluczone, że samoograniczanie polowań myśliwskich i rugowanie ze swojego grona niegodnych myśliwych zaowocowałyby dobrym przykładem. Niestety, również przedwojenne towarzystwa ochrony zwierząt nie wykazały większej inicjatywy $\mathrm{w}$ walce z kłusownictwem.

\section{Streszczenie}

Kłusownictwo jest przestępstwem znanym od wieków i bardzo trudnym do zwalczania we wszystkich krajach na świecie. W II Rzeczypospolitej zjawisko to stanowiło ogromny problem i nigdy nie zostało wyeliminowane ani nawet poważnie ograniczone. Międzywojenna policja, straż leśna, a także środowisko myśliwskie próbowały przeciwstawić się nielegalnym polowaniom. Na kłusowników organizowano zasadzki, konfiskowano ich nielegalnie posiadaną broń, likwidowano zastawiane pułapki. Takie działania nie przynosiły jednak oczekiwanych efektów.

Kłusownicy tworzyli hermetyczne, bezwzględne środowisko. Ich działalności sprzyjała akceptacja mieszkańców wsi i miasteczek, z których się wywodzili. Nielegalnie polujący byli nie tylko brutalni dla osaczonej zwierzyny. Zabijali myśliwych, leśników, a zdeterminowani nie wahali się strzelać do ścigajacych ich policjantów. Wobec polskich kłusowników dużą pobłażliwość stosowały sądy, które często orzekały bardzo niskie kary. Takie decyzje sprawiały, że kłusownicy nabierali pewności siebie. Ten proceder przestępczy uprawiali nie tylko biedni i głodni mieszkańcy polskich wsi. Wśród kłusowników znaleźć można było profesjonalistów, którzy mięso i skóry dostarczali do większych miast. W Wilnie, Lwowie, Krakowie i Warszawie nielegalny towar kupowali od nich masarze, restauratorzy i garbarze. Śmiało więc niektóre przypadki kłusownictwa w Polsce przed 1939 r. można zaliczyć do przestępczości zorganizowanej.

W lasach i na polach zakładano nie tylko wnyki. W niektórych regionach Polski w zatrważającym tempie znikały sarny, zające, dziki i łosie. Na Polesiu niezamożna ludność masowo 
odławiała żółwie, które za niewielkie pieniądze sprzedawała handlarzom. W Małopolsce Zachodniej chwytano różne gatunki ptaków i prawdopodobnie transportowano je do Niemiec, gdzie gatunki te były już bardzo rzadkie. O problemie tym informowała międzywojenna prasa.

\section{Poaching in the Second Republic of Poland}

Poaching is a crime known for centuries and very difficult to fight against all over the world. In the Second Republic of Poland the phenomenon was a huge problem and was neither eliminated nor reduced. The interwar police, forest guards and hunting communities sought to stem illegal hunting. There were ambushes prepared to catch them, their illegal weapons were confiscated, their traps and snares were liquidated, but none of it yielded the desired results.

Poachers made a hermetic, ruthless community. But their activities were treated with acceptance by the inhabitants of their native villages and towns. Poachers were ruthless not only towards animals. They killed hunters and foresters, and when they were determined, they did not hesitate to fire at pursuing policemen Also Polish courts were indulgent with poachers meting out very low penalties. This further emboldened them. Illegal hunting was practiced not only by poor and hungry inhabitants of local villages, but also professionals who were selling meat, hides and pelt in towns and cities. In Vilnius, Lviv, Krakow and Warsaw illegal goods were bought by butchers, inn owners, and tanners. Thus, some cases of poaching in interwar Poland could be regarded as organised crime.

Poachers did not limit themselves to set snares and traps in forests and meadows. In some regions of Poland deer, hares, boars, and moose were disappearing at alarming pace. In Polesie, poor people were known to catch large numbers of turtles which they sold cheaply to treaders. In western part of Little Poland various species of birds were caught and probably transported to Germany, where those species were already very rare. The problem was signalled by the interwar press.

\section{Bibliografia}

Badeni S., Szczęśliwe dni i inne wspomnienia myśliwskie Janusza Jędrzejewicza i Michała Kryspina Pawlikowskiego, wybór, oprac., wstęp i przypisy J.A. Radomski, Warszawa 2011.

Dwudziestolecie międzywojenne, t. XXXIV: I. Kienzler, Darz bór (myśliwi i leśnicy), Warszawa 2014.

Krawczyk J., Lasy Drugiej Rzeczpospolitej $w$ dawnych zapisach prasowych. Wydarzenia zwykte i niezwykte, Warszawa 2010.

Łozińska M., W ziemiańskim dworze. Codzienność, obyczaje, święta, zabawy, Warszawa 2011. Mich W., Ideologia polskiego ziemiaństwa 1918-1939, Lublin 2000.

Piątkowska M., Życie przestepcze w przedwojennej Polsce. Grandesy, kasiarze, brylanty, Warszawa 2012.

Biog ram: Remigiusz Kasprzycki - dr; adiunkt w Instytucie Nauk o Bezpieczeństwie Uniwersytetu Pedagogicznego w Krakowie. Autor książek: Opozycja polityczna w Krakowie w latach 1988-1989 (2003), Rakowice-Czyżyny w latach 1921-1955. Krakowskie lotnisko w stużbie wojskowej $i$ cywilnej (2010), Dekada buntu. Punk w Polsce i krajach sqsiednich $w$ latach 1977-1989 (2013). Zainteresowania naukowe koncentruje na historii społeczno-politycznej Polski w XX w. E-mail: remigiusz.kasprzycki@up.krakow.pl. 